\title{
Korelasi antara dimensi vertikal oklusi dengan panjang jari kelingking pada sub-ras Deutro Melayu
}

Cytha Nilam Chairani* dan Eni Rahmi**

*Fakultas Kedokteran Gigi, Universitas Andalas, Padang, Sumatera Barat, Indonesia

**Departemen Prostodonti, Fakultas Kedokteran Gigi, Universitas Andalas, Padang, Sumatera Barat, Indonesia

*JI Perintis Kemerdekaan No 77, Padang, Sumatera Barat, Indonesia; e-mail: cythachairani@gmail.com

Submisi: 10 Mei 2016; Penerimaan: 2 Juli 2016

\begin{abstract}
ABSTRAK
Penentuan dimensi vertikal oklusi (DVO) yang tepat merupakan salah satu faktor penting yang perlu diperhatikan dokter gigi dalam prosedur klinis perawatan gigi. DVO adalah jarak antara dua titik anatomi yang dipilih, yaitu satu titik pada maksila dan satu titik pada mandibula ketika posisi oklusi sentrik. Beberapa metode dianjurkan dalam pengukuran DVO. Salah satu metode penentuan DVO yang dikembangkan oleh para ahli yaitu metode antropometri. Metode ini dilakukan dengan cara pengukuran panjang jari kelingking. DVO dan panjang jari kelingking berbeda pada setiap ras manusia karena masing-masing ras memiliki ciri-ciri spesifik yang berbeda antara satu dengan yang lain. Sub ras Deutro Melayu merupakan salah satu sub ras di Indonesia. Penelitian ini bertujuan untuk mengetahui korelasi antara hasil pengukuran DVO dan panjang jari kelingking pada sub ras Deutro Melayu di Kota Padang. Penelitian ini merupakan penelitian observasional analitik dengan pendekatan cross sectional. Sampel sebanyak 112 warga Kota Padang yang merupakan sub ras Deutro Melayu dan memenuhi kriteria, terdiri dari 56 orang laki-laki dan 56 orang perempuan. Data diuji secara statistik dengan analisis Pearson correlation. Terdapat korelasi yang bermakna antara hasil pengukuran DVO dengan panjang jari kelingking dengan nilai $r=0,768$ dan hasil kedua pengukuran ini menunjukkan nilai yang hampir sama dengan nilai $p=0,000$, sehingga signifikan secara statistik $(p<0,05)$. Pengukuran antropometri panjang jari kelingking merupakan metode yang dapat digunakan untuk menentukan DVO.
\end{abstract}

Kata kunci: dimensi vertikal oklusi, jari kelingking, sub ras Deutro Melayu

\begin{abstract}
Correlation between VDO with length of little finger in Malay Deutro sub race. The correct determination of vertical dimension of occlusion (VDO) is an important step to to concern for dentist in clinical procedures of dental treatment. VDO is defined as the distance between two selected anatomic points, one point on maxilla and the other on mandibule in centric occlusion. There are various measurements of VDO methods suggested. Recently, many researchers have been studied antropometric method to determine the VDO. One of the antropometric methods is the length of little finger measurement. VDO and length of little finger are influenced by human race and each race has different specific characteristic. This study choose Malay Deutro sub race as one of sub-races in Indonesia. The purpose of this study is to determine the correlation between measurement of DVO and length of little finger of Malay Deutro sub race in Padang. This study use observational analysis with cross sectional approach. The samples consist of 56 males and 56 females, 112 respondents in total. The respondents are Malay Deutro sub race that domicile in Padang and are eligible. The data were analyzed by Pearson correlation test. VDO and length of little finger of Malay Deutro sub race was significantly correlated ( $r$ value $=0,768)$ and the result of VDO was almost equal with length of little finger $(p$ value= $0,000)$ that means statistically significant. The Antropometric parameter measurement of the length of little finger can be used in determination of VDO.
\end{abstract}

Keywords: vertical dimension of occlusion, little finger, Malay Deutro sub race

\section{PENDAHULUAN}

Penentuan dimensi vertikal yang tepat merupakan salah satu tahap penting dalam prosedur klinis yang memberikan informasi tentang hubungan vertikal dari mandibula terhadap maksila. ${ }^{1,2}$ Penentuan ini menjadi dasar dalam perawatan gigi dari penegakan diagnosis hingga terapi dari sistem stogmatognasi, prosedur rehabilitatif prostodonti, maupun prosedur rehabilitatif lainnya. Tahap tersebut secara signifikan tidak boleh terabaikan supaya fungsi optimal dan estetik dapat tercapai. ${ }^{2,3}$ Menurut Glossary of Prosthodontic Terms, "dimensi vertikal adalah jarak antara dua titik anatomi yang dipilih, yaitu satu titik pada maksila dan satu titik pada mandibula". Dimensi vertikal dibagi atas dimensi vertikal oklusi (DVO) dan dimensi vertikal istirahat (DVI). ${ }^{4}$ 


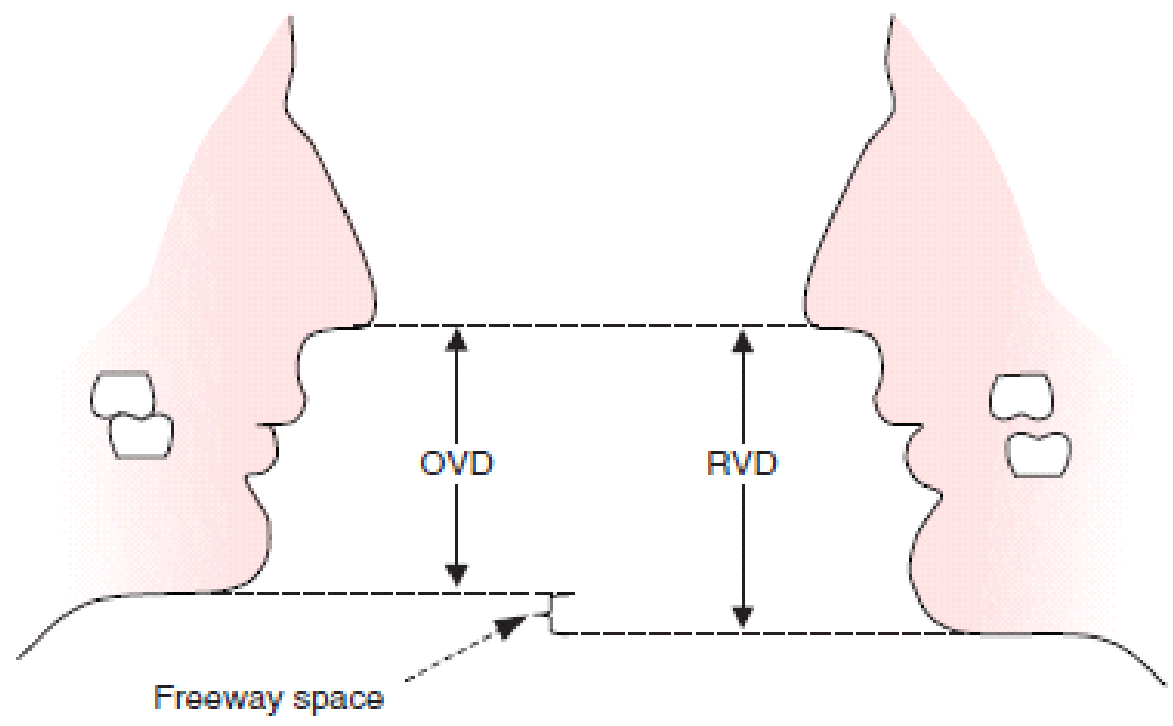

Gambar 1. Perbedaan dimensi vertikal oklusi dan istirahat ${ }^{1}$

Keterangan: $O V D=$ Occlusion Vertical Dimension $=$ Dimensi vertikal oklusi; $R V D=$ Rest Vertical

Dimension $=$ Dimensi vertikal istirahat

Dimensi vertikal oklusi adalah jarak antara dua titik anatomi yang dipilih ketika posisi oklusi sentrik, sedangkan dimensi vertikal istirahat merupakan jarak antara dua titik anatomi yang dipilih ketika mandibula dalam keadaan posisi istirahat fisiologis. ${ }^{4}$ Dalam keadaan normal, gigi-gigi tidak berkontak saat posisi istirahat pada pasien yang memiliki gigi geligi. Ruang yang terbentuk antara gigi-gigi pada posisi istirahat ini disebut Free Way Space (FWS). Ketika beroklusi, gigi geligi kontak satu sama lain dan ruang ini akan hilang. DVO selalu lebih kecil 2 $-4 \mathrm{~mm}$ dari dimensi vertikal istirahat (Gambar 1). ${ }^{5}$

Dokter gigi bertanggung jawab untuk menentukan nilai DVO dengan tepat dalam melakukan perawatan. ${ }^{6}$ Pada pelaksanaannya, penentuan DVO bukanlah sesuatu yang mudah terutama pada pasien usia lanjut yang telah lama mengalami edentulous total atau sebagian. Beberapa faktor dianggap bertanggung jawab terhadap timbulnya ambiguitas dalam pengukuran DVO, antara lain: kesulitan saat melakukan pengukuran pada kulit wajah karena sulit menentukan titik landmark, serta terdapatnya perubahan dalam keadaan psikologis dan patologis. Oleh karena itu, untuk memperoleh hasil yang akurat dianjurkan beberapa metode pengukuran DVO karena hasil pengukuran satu metode belum tentu sama dengan metode lainnya. Metode yang akan digunakan dalam menentukan DVO harus memenuhi kriteria, antara lain: pengukuran yang akurat dan dapat diulang, teknik yang mudah diadaptasikan, tipe dan kelengkapan alat yang dibutuhkan, serta waktu yang dibutuhkan lebih singkat. ${ }^{7}$ Meskipun demikian, belum ada pendapat yang menyatakan suatu metode lebih akurat dibandingkan metode lain., ${ }^{3,-11}$ Para ahli dalam penelitiannya telah mengembangkan metode untuk menentukan dimensi vertikal yaitu metode konvensional dan antropometri. ${ }^{5,12,13}$

Salah satu metode konvensional yang digunakan secara luas oleh dokter gigi di Indonesia yaitu two dot technique. Metode konvensional secara garis besar dibagi atas metode mekanik dan fisiologis. Metode konvensional terdiri dari metode mekanik dan fisiologis. Metode mekanis antara lain menentukan relasi linggir, penggunaan gigi tiruan lama, serta catatan pra-ekstraksi dan pengukurannya. Salah satu pengukuran catatan pra-ekstraksi menggunakan two dot technique untuk mengukur tinggi sepertiga bagian bawah. Metode fisiologis termasuk penentuan posisi fisiologis istirahat, estetik, fonetik, ambang batas penelanan, serta sensasi taktil dan kenyamanan. ${ }^{5,12,13}$ Semua hasil perkiraan pengukuran DVO secara mekanis dan fisiologis dianggap sebagai nilai sementara sampai dilakukan observasi fonetik dan estetik. ${ }^{5}$ 
Metode antropometri merupakan salah satu cara yang dapat digunakan untuk penentuan DVO. ${ }^{3,6-11}$ Leonardo da Vinci dan Mc Gee (1947) ${ }^{14}$ menyatakan terdapat hubungan antara DVO dengan berbagai pengukuran antropometri. Pengukuran wajah digunakan untuk menentukan DVO, salah satunya proporsi wajah yaitu tinggi sepertiga wajah bagian bawah. ${ }^{3}$ Dewasa ini penggunaan antropometri jari tangan banyak diteliti sebagai pembanding dalam penentuan DVO. Hal ini disebabkan pengukuran panjang jari relatif lebih mudah dalam menentukan titik acuan. Kesulitan yang ditemukan dalam penentuan DVO dengan metode yang lain dapat teratasi. Disamping itu, radiografi pergelangan tangan telah digunakan untuk pemeriksaan pertumbuhan struktur dentofasial sebagai indikator kematangan skeletal tulang dan ossifikasi dari tulang carpal, metacarpal, dan phalangeal. Pemeriksaan kematangan tulang biasanya berdasarkan pada derajat penyatuan epifisis dari tulang ulna dan radius. ${ }^{3,6,8-11}$

Dalam beberapa penelitian, antropometri panjang jari yang digunakan untuk dibandingkan dengan DVO antara lain panjang ibu jari, ${ }^{9}$ jari telunjuk, ${ }^{6}$ jari tengah, ${ }^{3}$ jari kelingking, ${ }^{3,6,8,8,10,11}$ serta jarak antara ujung ibu jari dan ujung jari telunjuk. ${ }^{7}$ Hasil penelitian tersebut menunjukkan pengukuran panjang jari kelingking dianggap memenuhi kriteria sehingga dapat digunakan untuk menentukan DVO.3,6,8,10,11 Dari penelitian yang dilakukan oleh Aruna Bhandari, dkk, ${ }^{8}$ Ruchi Ladda, dkk, ${ }^{6}$ Faraisoon MA, dkk, ${ }^{11}$ serta Kalra Divya, dkk ${ }^{3}$ dapat disimpulkan bahwa hasil pengukuran panjang jari kelingking hampir sama dengan nilai DVO sehingga dapat digunakan untuk memprediksi DVO. Metode ini ekonomis,dapat diandalkan, sederhana, inovatif, non-invasif, dan tidak memerlukan peralatan yang sulit didapatkan. ${ }^{3,6,8,10,11}$

Penggunaan metode penentuan DVO dengan pengukuran antropometri jari kelingking memiliki banyak kelebihan, namun penelitian mengenai metode ini masih sedikit. Penelitian-penelitian yang telah dilakukan sebagian besar dilakukan dengan menggunakan populasi India. ${ }^{3,6-10}$ Jika penelitian ini dilakukan pada ras yang berbeda, hasil yang diperoleh mungkin akan bervariasi karena setiap ras manusia memiliki ciri-ciri yang spesifik antara satu dengan yang lain. ${ }^{15} \mathrm{Di}$ Indonesia, penelitian pengukuran antropometri jari tangan telah diteliti oleh Elisabeth Saragih yaitu panjang jari telunjuk, jari kelingking, dan jarak ujung ibu jari sampai jari telunjuk pada suku Batak Toba. ${ }^{16}$

Penduduk Indonesia tersusun atas berbagai macam ras yang secara turun temurun membentuk variasi suku bangsa yang terbagi menjadi tiga kelompok, yaitu Sub ras Proto Melayu dan Sub ras Deutro Melayu yang tergolong dalam Sub Ras Malayan Mongoloid, sedangkan suku bangsa Tionghoa yang tergolong dalam Sub Ras Asiatic Mongoloid. ${ }^{17}$ Penduduk Indonesia yang termasuk Sub ras Deutro Melayu terdiri dari suku bangsa Aceh, Minangkabau, Bugis, Makasar, Sasak, Bali, Melayu, dan Jawa. ${ }^{18}$ Menurut data Badan Pusat Statistik (BPS) Kota Padang tahun 2010, suku bangsa yang termasuk sub ras Deutro Melayu yang terdata di Kota Padang antara lain Minangkabau, Jawa, Melayu, Aceh, Betawi, dan Sunda. Suku Minangkabau merupakan suku bangsa dengan jumlah penduduk terbanyak dari semua suku bangsa tersebut. ${ }^{19}$ Tujuan dari penelitian ini adalah untuk mengetahui korelasi antara hasil pengukuran DVO dengan panjang jari kelingking pada Sub ras Deutro Melayu di Kota Padang.

\section{METODE PENELITIAN}

Desain penelitian ini adalah observasional analitik yang berbentuk studi cross sectional. ${ }^{20}$ Penelitian ini dilakukan di Kota Padang dari tanggal 2 - 19 Februari 2015. Penelitian dilakukan setelah mendapatkan ethical clearance. Sampel dipilih sesuai kriteria inklusi yang berjumlah 112 orang. Sampel diberikan informasi sebelum dilakukan kegiatan penelitian. Kegiatan penelitian terdiri atas pengisian kuesioner, penandatanganan informed consent, serta pemeriksaan klinis rongga mulut dan jari kelingking. Pengukuran DVO dilakukan dengan two dot technique pada titik subnation dan gnation, kemudian dilakukan pengukuran panjang jari kelingking sebelah kanan dari ujung hingga pangkal jari kelingking atau ke titik paling jauh lipatan metacarpophalangeal $(M C P)$ digiti $V$, ketika tangan dibentangkan. Kedua pengukuran tersebut diukur dengan menggunakan vernier caliper digital (Gambar 2). Data yang diperoleh dianalisis dengan menggunakan uji Pearson's correlations. 


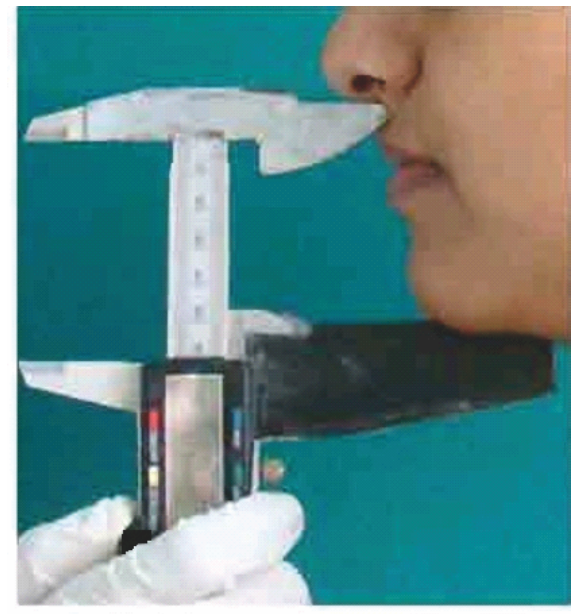

(A)

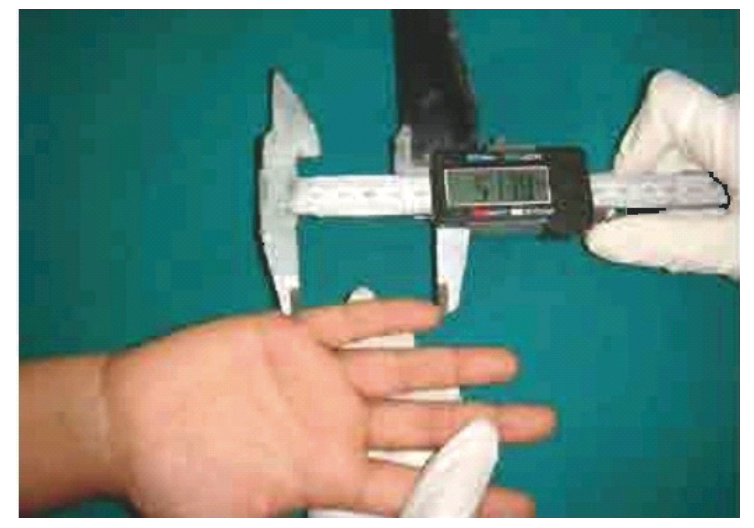

(B)

Gambar 2. (A) Pengukuran Dimensi Vertikal Oklusi (DVO). (B) Panjang Panjang Jari Kelingking (PJK)

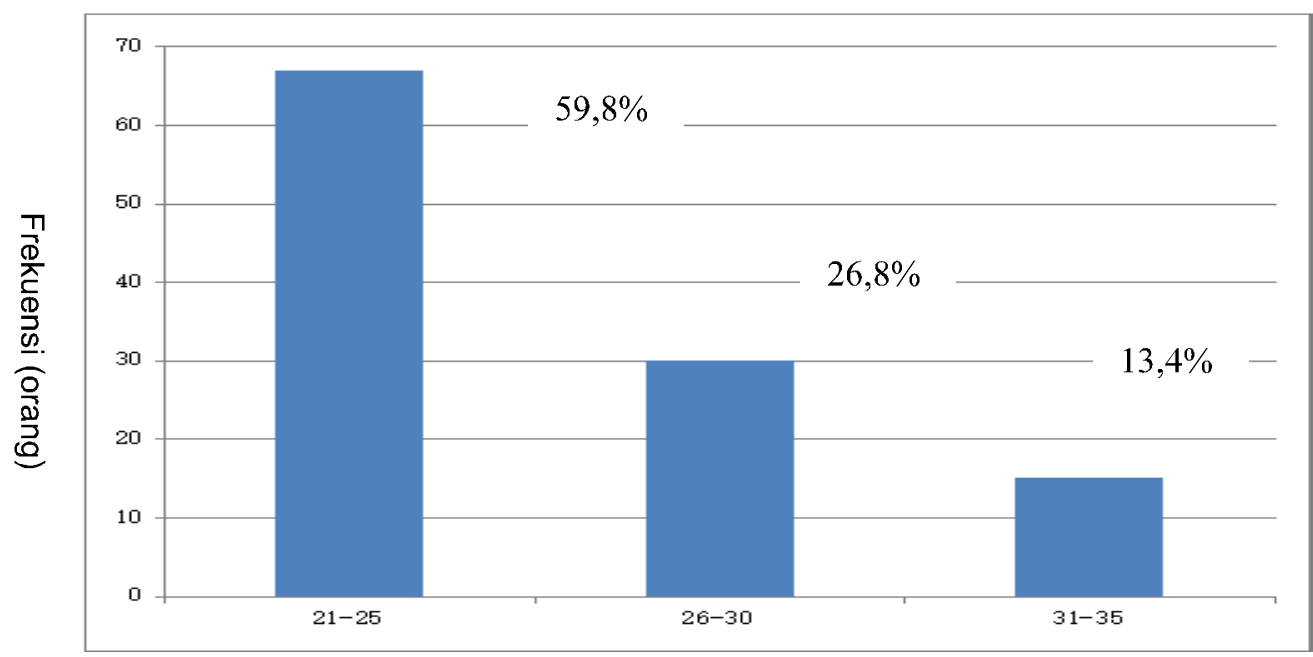

Umur (tahun)

Gambar 3. Distribusi umur sampel penelitian

\section{HASIL PENELITIAN}

Analisis univariat dilakukan untuk melihat distribusi frekuensi umur dandeskripsi statistik hasil pengukuran DVO dan panjang jari kelingking sampel penelitian.Penelitian ini dilakukan pada sampel penelitian yang memiliki umur berkisar 2135 tahun. Data disusun dalam beberapa rentang usia seperti yang terlihat pada Gambar 3.

Deskripsi statistik hasil pengukuran DVO dan panjang jari kelingking pada sub ras Deutro Melayu ditunjukkan pada Tabel 1, sedangkan hasil pengukuran DVO dan panjang jari kelingking pada laki-laki dan perempuan ditunjukkan pada Tabel 2.

Tabel 1. Deskripsi statistik hasil pengukuran Dimensi Vertikal Oklusi (DVO) dan Panjang Jari Kelingking (PJK)

\begin{tabular}{cccccc}
\hline $\begin{array}{c}\text { Pengukuran } \\
(\mathrm{mm})\end{array}$ & $\mathrm{n}$ & $\begin{array}{c}\text { Rata- } \\
\text { Rata } \\
(\mathrm{mm})\end{array}$ & $\begin{array}{c}\text { Minimum } \\
(\mathrm{mm})\end{array}$ & $\begin{array}{c}\text { Maksimum } \\
(\mathrm{mm})\end{array}$ & $\begin{array}{c}\text { s.b. } \\
(\mathrm{mm})\end{array}$ \\
\hline DVO & 112 & 62,42 & 52,31 & 73,11 & 4,12 \\
PJK & 112 & 60,68 & 49,90 & 72,78 & 4,72 \\
\hline
\end{tabular}


Tabel 2. Deskripsi statistik hasil pengukuran Dimensi Vertikal Oklusi (DVO) dan Panjang Jari Kelingking (PJK) pada Laki-Laki dan Perempuan

\begin{tabular}{|c|c|c|c|c|c|c|}
\hline Jenis Kelamin & $\mathrm{n}$ & Pengukuran (mm) & $\begin{array}{l}\text { Rata-Rata } \\
(\mathrm{mm})\end{array}$ & $\begin{array}{c}\text { Minimum } \\
(\mathrm{mm})\end{array}$ & Maksimum (mm) & $\begin{array}{l}\text { s.b. } \\
(\mathrm{mm})\end{array}$ \\
\hline \multirow{2}{*}{ Laki-Laki } & \multirow{2}{*}{56} & DVO & 64,76 & 56,30 & 73,11 & 3,40 \\
\hline & & PJK & 63,24 & 54,39 & 72,78 & 3,99 \\
\hline \multirow{2}{*}{ Perempuan } & \multirow{2}{*}{56} & DVO & 60,08 & 52,13 & 67,78 & 3,40 \\
\hline & & PJK & 58,12 & 49,90 & 67,62 & 3,97 \\
\hline
\end{tabular}

Tabel 3. Korelasi antara hasil pengukuran Dimensi Vertikal Oklusi (DVO) dengan Panjang Jari Kelingking (PJK)

\begin{tabular}{cccc}
\hline & $\mathrm{N}$ & Koefisien korelasi & PJK \\
\hline \multirow{2}{*}{ DVO } & \multirow{2}{*}{112} & $\mathrm{R}$ & 0,768 \\
& & $\mathrm{P}$ & 0,000 \\
\hline
\end{tabular}

Korelasi antara hasil pengukuran DVO dengan panjang jari kelingking ditunjukkan pada tabel 3, sedangkan Tabel 4 menerangkan korelasi antara kedua hasil pengukuran tersebut pada lakilaki dan perempuan. Berdasarkan Tabel 3 diketahui korelasi antara hasil pengukuran DVO dan panjang jari kelingking pada sub ras Deutro Melayu adalah sangat kuat dan berpola positif, artinya semakin besar nilai DVO semakin panjang jari kelingkingnya.

Hasil analisis data pada Tabel 4 menunjukkan korelasi antara hasil pengukuran DVO dan panjang jari kelingking pada laki-laki dan perempuan adalah kuat dan berpola positif. Hasil uji statistik memperlihatkan adanya korelasi antara hasil pengukuran DVO dan panjang jari kelingking pada laki-laki dan perempuan dengan nilai $p$ 0,000 yang berarti signifikan.

Tabel 4. Korelasi antara hasil pengukuran Dimensi Vertikal Oklusi (DVO) dengan Panjang Jari Kelingking (PJK) pada LakiLaki dan Perempuan

\begin{tabular}{|c|c|c|c|c|}
\hline Jenis Kelamin & & $\mathrm{n}$ & $\begin{array}{c}\text { Koefisien } \\
\text { korelasi }\end{array}$ & PJK \\
\hline \multirow{2}{*}{ Laki-Laki } & \multirow{2}{*}{ DVO } & \multirow{2}{*}{63} & $\mathrm{R}$ & 0,676 \\
\hline & & & $\mathrm{P}$ & 0,000 \\
\hline \multirow{2}{*}{ Perempuan } & \multirow{2}{*}{ DVO } & \multirow{2}{*}{63} & $\mathrm{R}$ & 0,670 \\
\hline & & & $P$ & 0,000 \\
\hline
\end{tabular}

\section{PEMBAHASAN}

Pengukuran DVO dan panjang jari kelingking dilakukan pada individu dengan pola pertumbuhan yang normal dan memiliki proporsi yang harmonis antara satu bagian tubuh dengan yang lainnya. ${ }^{3}$
Istilah "peramalan proporsi" yang dipopulerkan oleh Leonardo Da Vinci mengembangkan teori cannon yang sebelumnya dijelaskan oleh Vitruvius Polio bahwa proporsi anterior wajah secara Vertikal dapat dibagi menjadi tiga bagian yang sama dan DVO dideskripsikan sebagai sepertiga wajah bagian bawah. Pengukuran wajah dan tubuh telah banyak digunakan untuk menentukan DVO. Teori Leonardo $\mathrm{Da}$ Vinci yang lain menghubungkan panjang kepala dan tinggi badan yang disebut teori Leonardo Da Vinci 1, sedangkan teori Leonardo Da Vinci 2 membandingkan tinggi telinga dengan perbandingan proporsi wajah. Pengukuran antropometri telah digunakan untuk menentukan proporsi bagian tubuh dengan menggunakan golden proportion yang secara spesifik memiliki rasio $1.1618: 1.3,7$

Hasil penelitian ini sejalan dengan teori Leonardo Da Vinci, bahwa terdapat korelasi antara DVO dengan berbagai pengukuran antropometri, termasuk panjang jari kelingking. ${ }^{14}$ Hasil ini juga hampir sama dengan penelitian-penelitian lain. Beberapa penelitian yang dilakukan terhadap populasi India menyatakan bahwa pengukuran DVO memiliki nilai yang signifikan terhadap panjang jari kelingking pada laki-laki dan perempuan. ${ }^{6,8,10}$ Hasil penelitian lain yang dilakukan terhadap populasi Kurdish menunjukkan pengukuran DVO juga memiliki nilai yang signifikan dan korelasi positif terhadap panjang jari kelingking pada laki-laki dan perempuan. ${ }^{11}$

Dari penelitian ini juga diketahui DVO dan panjang jari kelingking laki-laki lebih besar daripada perempuan. Hasil ini sesuai dengan teori seksual dimorfisme yang menyatakan bahwa lakilaki memiliki nilai pengukuran tubuh yang lebih besar dibandingkan perempuan. Hal yang sama juga dijelaskan dari hasil beberapa penelitian 
sebelumnya bahwa hasil pengukuran DVO pada laki-laki lebih tinggi dibandingkan perempuan serta laki-laki memiliki jari kelingking lebih panjang daripada perempuan..$^{6,8,10,11}$

Seksual dimorfisme adalah suatu karakteristik perbedaan fisik yang berhubungan dengan jenis kelamin. Perbedaan ini ditunjukkan pada perbedaan sistemik antara laki-laki dan perempuan seperti ukuran, bentuk, warna, dan lain-lain. Salah satu perbedaan tersebut adalah karakteristik dari rangka tulang, yaitu profil tulang dan tulang tengkorak yang lebih menonjol pada laki-laki daripada perempuan. ${ }^{21}$ Seksual dimorfismeini berhubungan dengan fase postpubertas yang dipengaruhi oleh hormon androgen. ${ }^{3}$

Pada penelitian ini dilakukan pada sampel yang terdiri atas 56 orang laki-laki dan 56 orang perempuan yang memenuhi kriteria sebagai sampel. Kriteria sampel yang digunakan, antara lain: sampel yang memiliki sub ras Deutro Melayu minimal dua generasi diatasnya yang berdomisili di kota Padang dengan umur 21-35 tahun, 28 giginya telah erupsi lengkap, dan relasi dental kelas 1 Angle. Kriteria umur yang sama digunakan oleh penelitianpenelitian yang lain. Penelitian yang dilakukan oleh Ruchi Ladda dengan sampel sebanyak 60 orang subjek bergigi, terdiri dari 30 orang laki-laki dan 30 orang perempuan dengan usia berkisar antara 20-30 tahun. ${ }^{8}$ Begitu juga penelitian lain yang dilakukan oleh Bandhari kepada 400 orang subyek bergigi, terdiri atas 200 orang laki-laki dan 200 orang perempuan dengan umur 20-30 tahun. ${ }^{6} \mathrm{Hal}$ yang sama pada penelitian Faraisoon kepada 200 orang subyek bergigi pada laki-laki dan perempuan yang memiliki umur 20-30 tahun. ${ }^{11}$

DVO merupakan tinggi sepertiga wajah bagian bawah yang menghubungkan antara titik subnation yang terdapat pada kraniofasial dan titik gnation pada mandibula. Faktor-faktor yang dapat mempengaruhi DVO saat pertumbuhan dan perkembangan, antara lain: pertumbuhan kraniofasial, mandibula, erupsi gigi, dan oklusi. DVO akan mencapai ukuran yang maksimal apabila proses tumbuh kembang tersebut telah sempurna. ${ }^{22}$
Menurut Valadian dan Porter, ${ }^{23}$ semua individu sehat memiliki fase pertumbuhan yang hampir sama. Fase dewasa muda terjadi pada rentang usia yang sama terhadap kedua jenis kelamin, tetapi fase ini terjadi lebih awal pada perempuan yaitu berusia 10-18 tahun, sedangkan pada laki-laki berusia 1220 tahun. Menurut Hasil Rapat Kerja UKK Pediatri Sosial, masa pubertas perempuan lebih cepat sekitar umur 8-18 tahun dibandingkan laki-laki yaitu pada umur 10-20 tahun. ${ }^{24}$ Berdasarkan hal tersebut fase pertumbuhan pada perempuan dua tahun lebih awal dibandingkan laki-laki.

Penelitian yang dilakukan oleh Love, $\mathbf{d k k}^{25}$ mengenai perubahan skeletal kraniofasial dan gigi geligi saat post pubertas dengan sefalogram lateral kelas 1 pada sampel yang memiliki umur 16, 18, dan 20 tahun. Pertumbuhan mandibula yang sigfinikan ditemukan pada periode umur 16-18 tahun daripada periode umur 18-20 tahun. Pertumbuhan mandibula secara keseluruhan dua kali lebih cepat daripada maksila. ${ }^{2}$ Selama periode pertumbuhan, maksila dan mandibula mengalami rotasi terhadap basis anterior kranium yang dilihat dari lateral. Rotasi ini terjadi dalam arah keatas dan kedepan yang mengubah rahang selama masa pertumbuhan, khususnya pada bidang vertikal. Pertumbuhan tersebut menghasilkan pertumbuhan vertikal yang lebih di posterior daripada di anterior. ${ }^{26,27}$

Pola pertumbuhan ini menunjukkan panjang ramus, sudut gonial mandibula, dan gigi geligi yang sedang erupsi akan mempengaruhi tinggi anterior wajah atau dimensi vertikal. Ketika ramus berkembang normal, bagian tengah wajah yang diukur dari glabella ke subnasion adalah sama dengan pengukuran wajah bagian bawah yaitu dari subnasion ke gnation saat masa pertumbuhan sudah selesai. Setelah pertumbuhan selesai, erupsi gigi penting untuk mempertahankan DVO. Gigi geligi maksila dan mandibula erupsi untuk mempertahankan kontak oklusal seperti halnya pertumbuhan wajah. ${ }^{22}$ Gigi molar ketiga mendapatkan ruangan untuk erupsi yang akan mencapai posisi akhir ketika umur 20 tahun. ${ }^{28}$

Pada sistem mastikasi terdapat tiga faktor kritis yang menjadi penghubung antara otot dan tulang, yaitu: sendi temporomandibular, periodonsium, dan 
oklusi gigi geligi. Menurut Moyers dan Wainright oklusi gigi geligi merupakan penghubung paling kritis yang menentukan pertumbuhan tulang dan kematangan neuromuskular. Hubungan tonjol bukal dari gigi posterior mandibula dan tonjol palatinal dari gigi posterior maksila secara anatomi berhadapan dengan fossa dan marginal ridge gigi antagonisnya yang mempertahankan jarak antara maksila dan mandibula setelah masa pertumbuhan selesai. ${ }^{29}$ Usia 20-35 tahun termasuk fase oklusi dewasa muda ketika kontak oklusi telah lengkap, pertumbuhan tulang telah selesai, dan gigi geligi belum mengalami perubahan oklusi seperti atrisi akibat pengunyahan dalam jangka waktu yang lama. ${ }^{30}$

Radiografi pergelangan tangan telah digunakan untuk pemeriksaan pertumbuhan struktur dentofasial sebagai indikator kematangan skeletal tulang pada berbagai fase perkembangan postnatal. Penentuan rangkaian ossifikasi dari tulang carpal, metacarpal, dan phalangeal dapat dilakukan pada sebagian besar anak yang sehat baik laki-laki maupun perempuan. Fase postpubertas pada perempuan berusia 15-17 tahun sedangkan 17-19 tahun pada laki -laki. Pemeriksaan kematangan tulang pada fase ini berdasarkan derajat penyatuan epifisis dari tulang ulna dan radius. Semua tulang carpal, metacarpal, dan phalangeal telah berkembang sempurna. ${ }^{31}$ Oleh karena itu, pengukuran DVO dan parameter antropometri panjang jari kelingking pada penelitian ini dilakukan pada umur 21-35 tahun. Hasil pengukuran DVO dan panjang jari kelingking pada penelitian ini dengan sampel berumur 21-35 tahun menunjukkan tidak ada perbedaan yang bermakna.

Dalam penelitian ini, peneliti menemukan beberapa keterbatasan, antara lain: penelitian ini hanya dilakukan pada sampel yang memiliki sub ras Deutro Melayu dan berdomisili di Kota Padang, sedangkan di Indonesia masih terdapat sub ras dan kelompok suku lainnya. Peneliti kesulitan dalam menentukan landmark pada titik gnation yang disebabkan oleh jaringan lunak pada dagu terutama pada pasien yang memiliki wajah bulat dengan jaringan lunak lainnya. Oleh karena itu, diperlukan metode penentuan DVO lainnya sebagai metode pembanding dalam menentukan nilai DVO yang tepat.

Saran yang disampaikan pada penelitian ini adalah Penelitian lebih lanjut diperlukan tentang pengukuran DVO dan panjang jari kelingking pada sub ras dan kelompok suku bangsa lain di Indonesia, penelitian selanjutnya diperlukan untuk membandingan pengukuran DVO dan panjang jari kelingking dengan parameter antropometri panjang jari tangan lainnya, penelitian selanjutnya perlu dilakukan pengukuran DVO dan panjang jari kelingking menggunakan radiografi sefalometri dan rontgen pergelangan tangan, penelitian gabungan atau join research dengan bidang ilmu kedokteran forensik karena hasil penelitian juga bermanfaat dalam prosedur identifikasi forensic.

\section{KESIMPULAN}

Berdasarkan penelitian yang telah dilakukan dapat disimpulkan bahwa terdapat korelasi yang sangat kuat antara hasil pengukuran DVO dan panjang jari kelingking pada sub ras Deutro Melayu, sehingga pengukuran antropometri panjang jari kelingking dapat digunakan sebagai metode pembanding dalam penentuan DVO.

\section{UCAPAN TERIMAKASIH}

Ucapan terimakasih kepada Bapak Kepala Satuan Polisi Pamong Praja Kota Padang dan Ibu Kepala Puskesmas Lubuk Buaya yang telah memberikan izin sehingga penulis dapat melaksanakan penelitiannya.

\section{DAFTAR PUSTAKA}

1. Basker RM, Davenport JC, Thomason JM. Prosthetic treatment of the edentulous patient $5^{\text {th }}$ Ed. New Delhi, India: Blackwell Publishing Ltd; 2011. 68, 151.

2. Delic Z, Simunovic-Soskic M, Pernic-Grzic R, Vukvojac S, Rajic Z, Kuna T, Kuna T. Evaluation of craniometric methods for determination of vertical dimension of occlusion. Coll Antropol. 2000; 1 : $31-35$. 
3. Karla D, Karla A, Goel S. Determination of vertical dimension of occlusion from anthropometric measurement of fingers an in vivo study. IJERMDC. 2015; 2(2): 10 - 15.

4. Glossary of Prosthodontics Terms. 8th ed. J Prosthet Dent 94; 2005: 10 - 85.

5. Zarb GA, Bolender CL, Eckert SE, Jacob RF, Fenton AH, Mericske-Stern R. Prosthodontic treatment for edentulous patient: complete dentures and implant supported prostheses $12^{\text {th }}$ ed. St Louis, MO: Mosby; 2004. 274 - 282.

6. Ladda R, Bhandari AJ, Kasat VO, Angadi GS. A new technique to determine vertical dimension of occlusion from anthropometric measurements of fingers. Indian J Dent Res. 2013; 24(3): $316-320$.

7. Rupesh PL, Subhas $S$, Salagundi $B, K M$ Regish, Poonacha VUP, dkk. Leonardo da vinci's divine proportion in establishing vertical dimension. J Ulti Dent Res. 2012; 1(2): 1 - 7.

8. Bhandari AJ, Ladda R, Bhandari AJ. Correlation between vertical dimension of occlusion and lenght of little finger. Pravara Med Rev. 2012; 4(4): 10 - 14.

9. Basnet BB, Parajuli PK, Singh RK, Suwal $P$, Shrestha P, Baral D. An anthropometric study to evaluate the correlation between the occlusal vertical dimension and length of the thumb. Clin Cosmet Investig Dent. 2015; 7: 33 -38 .

10. Nazir S, Zargar NM, Khursaid SZ, Shah AF, $\mathrm{Naz} F$, Malik M. Correlation between vertical dimension of occlusion and finger length in kashmiri population. Journal of Orofacial Research. 2015; 5(2): 37 - 39.

11. Miran FA, Mahmood KA. The correlation between the right little finger, eye - ear distance and vertical dimension of occlusion among students of faculty of medical sciences in university of sulaymani. IOSR Journal of Dental and Medical Sciences. 2015; 14(12): $69-73$.

12. Nallaswamy $\mathrm{D}$, Ramalingam $\mathrm{K}$, Bhat $\mathrm{V}$. Textbook of prosthodontics. New Delhi, India:
Jaypee Brothers Medical Publishers $(\mathrm{P}) \mathrm{Ltd}$; 2003. $129-133$.

13. Sarandha, Hussain Z, Uthkarsh. Textbook of complete denture prosthodontics. First Edition. New Delhi, India: Jaypee Brothers Medical Publishers (P) Ltd; 2007. 80 - 85.

14. McGee GF. Use facial mesurements in determining vertical dimension. J Am Dent Assoc 1947;35: 342 - 350.

15. Daldjoeni N. Ras-ras umat manusia. Bandung: Citra Aditya Bakti. 1991.

16. Saragih E. Nilai konversi jarak DVO dengan panjang jari tangan kanan pada suku batak toba [skripsi]. Medan: Universitas Sumatera Utara; 2015.

17. Takari M, dkk. Masyarakat kesenian di Indonesia. Studi Kultural. Universitas Sumatera Utara. 2008. 73.

18. Hartini D. Masyarakat prasejarah Indonesia [Internet]. Malang: SMU Terbuka; 2011 [Cited 7 November 2016]. Available from Academia: http://www.academia.edu/17575579/ MASYARAKAT_PRASEJARAH_INDONESIA. pdf

19. Badan Pusat Statistik (BPS) Kota Padang. Sensus penduduk tahun 2010.

20. Sastroasmoro S, Ismael S. Dasar-dasar metodologi penelitian klinis. Edisi ke-4. Jakarta: Sagung Seto. 2011. 100, 130.

21. Jebaraj A/L Devaprasad Emmanuel Chellapa Joel. Seksual dimorfisme pada ukuran gigi rahang bawah pada mahasiswa Malaysia FKG USU TA 2006-2010[skripsi]. Medan: Universitas Sumatera Utara; 2013.

22. Spear FM. Approches to Vertical Dimension. Advanced esthetics \& interdisciplinary dentistry. 2006; 2(3): 2.

23. Valadian I, Porter D. Physical growth and development: from conception to maturity. Boston, Jhon Wright-PSG; 1977.

24. Soetjiningsih. Tumbuh kembang anak. Jakarta: Penerbit Buku Kedokteran EGC; 1995. 
25. Love RJ, Murray JM, Mamandras AH. Facial growth in males 16 to 20 years of age. The American Journal of Orthodontics and Dentofacial Orthopedics. 1990; 97(3): $200-$ 206.

26. Sharma P, Arora A, Valiathan A. Age chages of jaws and soft tissue profile. The Scientific World Journal. 2014. 1 - 7.

27. Foster TD. Buku ajar ortodonsi. Edisi III. Diterjemahkan Oleh: drg. Lilian Yuwono. Jakarta: EGC Penerbit Buku Kedokteran. 14.

28. Nelson SJ, Ash MM. Wheeler's dental anatomy, physiology, and occlusion ninth edition. St. Louis, Missouri: Saunders, Elsevier Inc. 2010. 282, $299-303$.
29. Gregory M. Ness Dds; Larry JP. Peterson's principles of oral andmaxillofacial surgery second edition: Impacted Teeth. London: Bc Decker Inc. 2004. 139.

30. Harper PR, Misch CE. The clinical indication for altering vertical dimension of occlusion. 2000; 31(4).

31. UD Dent. Devolopment of occlusion [internet]. Saudi Arabia: Ud Dent, Dental Collage; 2014 [cited 4 Januari 2016]. Available from slideshare: http://slideshare.net/mobile/ UDDENT/devolopment-of-occlusion

32. Gilsanz V, Ratib O. Hand bone age: a digital atlas of skeletal maturity. VerlagBerlin Heidelberg: Springer; 2005. 16 - 17. 